\title{
Changes in Bone Mineral Density after Kidney Transplantation
}

\author{
Böbrek Nakli Sonrası Kemik Mineral Yoğunluğundaki Değişiklikler
}

\section{Emel IŞIKTAŞ SAYILAR \\ (D) 0000-0002-8824-6560 \\ İhsan ERGÜN \\ (D) 0000-0003-2066-5512}

Ufuk University Faculty of Medicine Department of Nephrology, Ankara, Turkey

\section{Corresponding Author Sorumlu Yazar \\ Emel IŞIKTAŞ SAYILAR \\ emelisiktas@yahoo.com}

Received / Gelis Tarihi : 24.01.2020

Accepted / Kabul Tarihi : 06.04.2020 Available Online /

Çevrimiçi Yayın Tarihi : 25.04.2020

\begin{abstract}
Aim: The aim of this study was to evaluate changes in lumbar and femoral bone mineral density (BMD) in the post-transplant period.

Material and Methods: A total of 69 consecutive adult ( $>18$ years of age) patients who underwent kidney transplantation between Jan 2016 and Jul 2019 were included in this retrospective study. The demographic features and laboratory findings of the patients (serum corrected calcium, phosphorus, alkaline phosphatase, creatinine, eGFR, i-parathormone and $25(\mathrm{OH})$ D vitamin levels) were recorded. BMD was evaluated by dual energy X-ray absorptiometry (DEXA).

Results: According to the DEXA results, lumbar and femoral $\mathrm{T}$ scores were $-1.1 \pm 1.3$ and $-1.1 \pm 1.1$, respectively. Lumbar assessment revealed osteoporosis in $12(17.4 \%)$ patients and osteopenia in $24(34.8 \%)$ patients. Femoral assessment revealed osteoporosis in $7(10.1 \%)$ patients and osteopenia in $29(42.0 \%)$ patients. The first year, 1-2 year and $>2$ years follow up data revealed osteoporosis in $4.3 \%, 5.8 \%$ and $7.2 \%$ of patients in the lumbar region and in $2.9 \%, 2.9 \%$ and $4.3 \%$ of patients in the femoral region, respectively. There was no significant difference in cumulative steroid dose between patients with BMD loss in the lumbar $(\mathrm{p}=0.197)$ and femoral $(\mathrm{p}=0.971)$ region and patients with normal BMD measurement. In addition, no significant relation was observed between the induction therapy and loss of BMD in the lumbar region $(\mathrm{p}=0.671)$ and femur $(\mathrm{p}=0.126)$.

Conclusion: As a result, $25(\mathrm{OH}) \mathrm{D}$ vitamin deficiency is quite common in transplant patients and the loss of BMD is observed especially in the lumbar region in the first year after transplantation.
\end{abstract}

Keywords: Kidney transplantation; bone mineral density; lumbar region; femoral; vitamin D.

\section{ÖZ}

Amaç: Bu çalışmanın amacı böbrek nakil sonrası dönemde lomber ve femoral kemik mineral yoğunluğundaki (KMY) değișiklikleri değerlendirmektir.

Gereç ve Yöntemler: Bu retrospektif çalışmaya, Ocak 2016 ve Temmuz 2019 tarihleri arasında böbrek nakli yapılan ardışık 69 erişkin (>18 yaş) hasta dahil edildi. Hastaların demografik özellikleri ve laboratuvar bulguları (serum düzeltilmiş kalsiyumu, fosfor, alkalen fosfataz, kreatinin, eGFR, i-parathormon ve $25(\mathrm{OH})$ D vitamin düzeyi) ile ilgili veriler kaydedildi. KMY, dual enerji X-ray absorbsiyometri (DEXA) ile değerlendirildi.

Bulgular: DEXA sonuçlarına göre, lomber ve femoral T skorları sırasıyla $-1,1 \pm 1,3$ ve $-1,1 \pm 1,1$ idi. Lomber değerlendirmede $12(\% 17,4)$ hastada osteoporoz ve $24(\% 34,8)$ hastada osteopeni saptandi. Femoral değerlendirmede $7(\% 10,1)$ hastada osteoporoz ve $29(\% 42,0)$ hastada osteopeni saptandı. İlk yıl, $1-2$ yıl ve $>2$ yıl takip verilerine göre, sırasılyla lomber bölgede hastaların $\% 4,3, \% 5,8$ ve $\% 7,2$ 'sinde, femurda hastaların $\% 2,9, \% 2,9$ ve $\% 4,3$ 'ünde osteoporoz saptandı. Lomber bölge $(\mathrm{p}=0,197)$ ve femurda $(\mathrm{p}=0,971)$ KMY kaybı tespit edilen hastalar ile KMY ölçümü normal olan hastalar arasında kümülatif steroid dozu açısından anlamlı bir fark yoktu. Ayrıca hastaların almış olduğu indüksiyon tedavisi ile lomber bölge $(p=0,671)$ ve femurda $(\mathrm{p}=0,126)$ gelişen KMY kaybı arasında anlamlı bir ilişki görülmedi.

Sonuç: Sonuç olarak, nakil hastalarında $25(\mathrm{OH})$ D vitamini eksikliği oldukça yaygındır ve özellikle nakilden sonraki ilk yll lomber bölgede belirgin olmak üzere KMY kaybı görülmektedir.

Anahtar kelimeler: Böbrek nakli; kemik mineral yoğunluğu; lomber bölge; femur; vitamin D. 


\section{INTRODUCTION}

Problems related to bone mineral density (BMD) is one of the complications associated with life-long immunosuppressive therapy in kidney transplant patients. This condition increases the length of hospital stay, treatment cost, and mortality and morbidity rates due to the increased fracture risk in kidney transplant recipients (1). Data from the two major studies on fracture and mortality rates in post-transplant patients revealed the incidence of fractures to be $3.4-3.8 \%$ and the 1-year mortality risk after fracture to be $9.0-11.0 \%$, depending on the risk factors $(2,3)$. Several factors have been implicated in the etiology of bone mineral disorders develop after kidney transplantation including immunosuppressive drugs along with duration of chronic renal failure, type and duration of dialysis, pretransplant bone disease (secondary hyperparathyroidism, osteomalacia, mixed bone disease, adynamic bone disease), diabetes mellitus, smoking, physical inactivity, menopause, fracture history, malnutrition, post-transplant persistent hyperparathyroidism and $25(\mathrm{OH})$ vitamin D deficiency (4,5). Immunosuppressive drugs, especially corticosteroids, reduce the number and activity of osteoblasts, increase osteoclastic activity and suppress bone formation resulting in rapid bone loss and increasing fracture risk via dosedependent inhibition of growth hormone release and insulinlike growth factor-1 synthesis. Moreover, these agents cause negative calcium balance by decreasing intestinal absorption and increasing renal excretion of calcium (6). Calcineurin inhibitors can also cause high bone turnover, especially leading to trabecular bone loss. The combined use of cyclosporine (CsA) and glucocorticoid leads to bone loss by inhibiting osteoblast differentiation and enhancement. Tacrolimus (Tac) has been shown to cause osteopenia in animals, but there is limited data regarding its effect on bones in humans $(5,7,8)$. Sirolimus, rapamycin, mycophenolate mofetil and azathioprine treatments were shown to have minimal effect on bone mass, and in vitro studies, everolimus has been shown to prevent bone resorption by inhibiting osteoclast cathepsin-K expression $(9,10)$.

There are studies showing that the risk of fractures increases as BMD decreases in transplant patients $(11,12)$. In this study, our aim was to show BMD changes in lumbar and femoral region in the post-transplant period.

\section{MATERIAL AND METHODS}

A total of 69 consecutive patients older than $>18$ years of age, who underwent kidney transplantation between January 2016 and July 2019 were included in this retrospective study. The blood biochemistry analysis was performed in routine controls including corrected serum calcium, phosphorus, alkaline phosphatase, creatinine, eGFR, i-parathormone and 25(OH) D vitamin level.

The study protocol was approved by the Ufuk University Faculty of Medicine Clinical Trials Ethics Committee (dated 16.12.2019 and numbered 5) and was conducted in accordance with the principles of Helsinki Declaration. Informed consent was obtained from all participants after informing them to participate in this research.

The 25(OH) D vitamin levels of the participants were studied by High Performance Liquid Chromatography (HPLC) method and vitamin D status was categorized as vitamin D deficiency $(<20 \mathrm{ng} / \mathrm{mL})$, vitamin D insufficiency (20-30 $\mathrm{ng} / \mathrm{mL}$ ), and normal vitamin D levels (>30 ng/mL, 13).
Anti-thymocyte globulin (Grafalon Neovii), one of the antilymphocyte antibodies, was given in $100 \mathrm{mg} / \mathrm{g}$ dose for 3 days as induction therapy on demand. All patients were started on prednisolone $(0.8 \mathrm{mg} / \mathrm{kg} / \mathrm{day}$, oral $)$ after intravenous $1500 \mathrm{mg}$ methyl-prednisolone treatment. Prednisolone was given as $30 \mathrm{mg} /$ day, $20 \mathrm{mg} /$ day and 5 $\mathrm{mg} /$ day, in the first month, in the second month and after the third month, respectively. In maintenance therapy, calcineurin inhibitor (Tac or Cs-A) and an antiproliferative agent (mycophenolate mofetil, maximum $2 \mathrm{~g} /$ day or mycophenolate sodium, maximum $1440 \mathrm{mg} / \mathrm{g}$ ) were used in combination with prednisolone therapy. Cs-A (6 $\mathrm{mg} / \mathrm{kg} /$ day, 2 oral doses daily) and Tac $(0.1 \mathrm{mg} / \mathrm{kg} /$ day, 2 oral doses daily) blood levels were titrated as needed to achieve target levels. In case of acute organ rejection, renal biopsy was performed and treatment (pulse methylprednisolone, anti-thymocyte globulin, plasmapheresis and intravenous immunoglobulin treatments alone or in combination) was performed according to Banff criteria. Bone mineral densitometry was evaluated by dual energy X-ray absorptiometry (DEXA). The shooting time and radiation dose were determined as 60 seconds and $42 \mu \mathrm{Gy}$ for lumbar region and femur. Results were determined as $\mathrm{T}$ score [defines the difference between the patient's BMD and the mean BMD of the standard young adult (20-30 years old) population as standard deviation (SD) and expresses peak bone mass] and Z score (standard deviation of difference of patient's BMD results with the mean BMD of controls in the same gender and age group). The $\mathrm{T}$ score $\leq-2.5 \mathrm{SD}$ was accepted as osteoporosis, and $\mathrm{T}$ score $<-1.0$ and >-2.5 SD was accepted as osteopenia.

\section{Statistical Analysis}

The Kolmogorov-Smirnov test was used to follow normal distribution of variables. For the variables assumed to be normally distributed, inter-group comparisons were made by Independent samples t-test, while Mann Whitney U test was used for non-normally distributed variables. Spearman's rank correlation analysis was used to test the relation between cumulative steroid dose and $25(\mathrm{OH}) \mathrm{D}$ vitamin levels and BMD measurements. Chi-square test was used to the test the relationships among the categorical variables. The $p$ value $<0.05$ was considered as statistically significant. The statistical analyses were performed with SPSS v.22.

\section{RESULTS}

Overall, 24.6\% $(\mathrm{n}=17)$ of the patients were female and $75.4 \%(\mathrm{n}=52)$ were male. The mean age of the patients was $40.7 \pm 13.8$ (range, 17.0 to 64.0 ) years, body mass index was $26.6 \pm 5.0$ (range, 18.7 to 42.5 ) $\mathrm{kg} / \mathrm{m}^{2}$, and post-transplant follow-up duration was $20 \pm 12$ (range, 1 to 41 ) months. The evaluation of patients' diseases underlying end-stage renal disease to be chronic glomerulonephritis in $23(33.3 \%)$ patients, hypertension in $12(17.4 \%)$ patients, diabetic nephropathy in $9(13.0 \%)$ patients, secondary amyloidosis in $8(11.6 \%)$ patients, chronic tubulointerstitial nephritis in $3(4.3 \%)$ patients, nephrolithiasis in $2(2.9 \%)$ patients, polycystic renal disease in $2(2.9 \%)$ patients and vesicoureteral reflux in $1(1.4 \%)$ patient. The etiology of end-stage renal disease was unknown in $9(13.0 \%)$ patients. When classified according to the reference values, there were $3(4.3 \%)$ patients with normal $25(\mathrm{OH})$ vitamin D 
levels, $11(15.9 \%)$ patients with $25(\mathrm{OH})$ vitamin D insufficiency and $55(79.7 \%)$ patients with $25(\mathrm{OH})$ vitamin $\mathrm{D}$ deficiency. The type of dialysis, tissue compliance number, transplantation type, the features of immunosuppression induction and maintenance treatment, rejection development and laboratory values of the patients are demonstrated in Table 1.

The mean $\mathrm{T}$ score for the lumbar region was $-1.1 \pm 1.3$ (range, -3.3 to 2.1), while the mean $\mathrm{T}$ score for the femur was $-1.1 \pm 1.1$ (range, -3.4 to 1.3 ). In lumbar region evaluation, osteoporosis was detected in $12(17.4 \%)$ patients and osteopenia was detected in 24 (34.8\%) patients. Five $(41.7 \%)$ of 12 patients who developed osteoporosis and $11(45.8 \%)$ of 24 patients who developed osteopenia received induction therapy. Looking at the relationship between lumbar region BMD loss and induction therapy; loss of BMD was observed in 16 $(55.2 \%)$ of the 29 patients given induction therapy, whereas BMD loss was observed in $20(50.0 \%)$ of the 40 untreated patients $(\mathrm{p}=0.671)$. According to femur measurements, osteoporosis was detected in $7(10.1 \%)$ patients and osteopenia in $29(42.0 \%)$ patients. Three $(42.9 \%)$ of 7 patients who developed osteoporosis and 9 (31.0\%) of 29 patients who developed osteopenia received induction therapy. Considering the relationship between BMD loss and induction therapy in the femoral region; while BMD loss was observed in 12 (41.4\%) of the 29 patients who received induction therapy, bone loss was observed in $24(60.0 \%)$ of the 40 patients who did not receive induction therapy $(\mathrm{p}=0.126)$. There were $4(5.8 \%)$ patients with osteoporosis in both regions and 14 (20.3\%) patients with osteopenia. Overall, 24 (34.8\%) patients had normal BMD. Fracture was noted in none of the patients during follow-up period (Table 2). Follow up data on BMD losses with respect to DEXA measurements of lumbar and femur area are shown in Table 3, Figure 1 and Figure 2. Follow up data on osteoporosis development in the first year, 1-2 years and >2 years revealed lumbar osteoporosis rates of $4.3 \%, 5.8 \%$ and $7.2 \%$, respectively, and femoral osteoporosis rates of $2.9 \%, 2.9 \%$ and $4.3 \%$, respectively. In addition, at the end of the first year, BMD loss in the lumbar region was higher than in the femur region, and the frequency of osteoporosis showed a cumulative increase in the post-transplant period.

Overall, 20 (29.0\%) patients developed acute rejection and therefore received $1500 \mathrm{mg}$ of methyl-prednisolone in addition to standard steroid treatment. When patients were evaluated in terms of the relationship between cumulative steroid dose and BMD; there was no significant difference in cumulative steroid dose between patients with BMD loss and with normal BMD measurement in the lumbar region $(p=0.197)$. In the femur region, there was no significant difference in cumulative steroid dose between patients with BMD loss and patients with normal BMD measurement $(\mathrm{p}=0.971$, Table 4$)$.

The evaluation of relation between $25(\mathrm{OH})$ vitamin $\mathrm{D}$ levels and BMD of the patients revealed no significant difference in $25(\mathrm{OH})$ vitamin $\mathrm{D}$ levels between patients with BMD loss and normal BMD measurement $(\mathrm{p}=0.909)$ in the lumbar region. There was also no significant difference in $25(\mathrm{OH})$ Vitamin D levels in patients with BMD loss and in patients with normal BMD measurements in the femur region $(p=0.177$, Table 4$)$.
Table 1. Demographic characteristics of patients, $n=69$

\begin{tabular}{|c|c|}
\hline \multicolumn{2}{|l|}{ Gender, n (\%) } \\
\hline Female & $17(24.6)$ \\
\hline Male & $52(75.4)$ \\
\hline Age (year) & $40.7 \pm 13.8$ \\
\hline BMI $\left(\mathrm{kg} / \mathbf{m}^{2}\right)$ & $26.6 \pm 5.0$ \\
\hline \multicolumn{2}{|l|}{ Dialysis type, n (\%) } \\
\hline Preemptive & $37(53.6)$ \\
\hline Hemodialysis & $30(43.5)$ \\
\hline Peritoneal dialysis & $2(2.9)$ \\
\hline \multicolumn{2}{|l|}{ Transplantation type, n (\%) } \\
\hline Live & $66(95.7)$ \\
\hline Cadaveric & $3(4.3)$ \\
\hline \multicolumn{2}{|l|}{ MM, n (\%) } \\
\hline $0 \mathrm{MM}$ & $5(7.2)$ \\
\hline $1 \mathrm{MM}$ & $4(5.8)$ \\
\hline $2 \mathrm{MM}$ & $10(14.5)$ \\
\hline $3 \mathrm{MM}$ & $24(34.8)$ \\
\hline $4 \mathrm{MM}$ & $11(15.9)$ \\
\hline $5 \mathrm{MM}$ & $8(11.6)$ \\
\hline $6 \mathrm{MM}$ & $7(10.1)$ \\
\hline \multicolumn{2}{|l|}{ Immunosuppression, n (\%) } \\
\hline Tac+MMF & $68(98.6)$ \\
\hline $\mathrm{CsA}+\mathrm{MMF}$ & $1(1.4)$ \\
\hline \multicolumn{2}{|l|}{ Induction treatment, $\mathrm{n}(\%)$} \\
\hline ATG & $28(40.6)$ \\
\hline Basiliximab & $1(1.4)$ \\
\hline Non-inducted & $40(58)$ \\
\hline Transplantation time (month) & $20.0 \pm 12.0$ \\
\hline Cumulative prednisolone dose (mg) & $6450.0 \pm 2486.8$ \\
\hline $25(\mathrm{OH})$ vitamin $\mathrm{D}(\mathrm{ng} / \mathrm{mL})$ & $11.1 \pm 10.0$ \\
\hline PTH (ng/L) & $148.3 \pm 217.5$ \\
\hline $\mathrm{Ca}(\mathrm{mg} / \mathrm{dL})$ & $9.3 \pm 0.4$ \\
\hline$P(\mathrm{mg} / \mathrm{dL})$ & $3.4 \pm 0.6$ \\
\hline $\operatorname{ALP}(\mathrm{U} / \mathrm{L})$ & $76.0 \pm 27.2$ \\
\hline
\end{tabular}

BMI: Body Mass Index, MM: Miss-Match number, MMF: Mycophenolate mofetil, Tac: Tacrolimus, CsA: Cyclosporine-A, PTH: Parathyroid Hormone, Ca: Calcium, P: Phosphorus, ALP: Alkaline phosphatase, ATG: Anti-thymocyte Globulin

Table 2. Patients' lumbar and femur BMD evaluations

\begin{tabular}{ccccc}
\hline \multicolumn{5}{c}{ Lumbar } \\
& Normal & Osteopenia & Osteoporosis & Total \\
\hline Normal & $24(34.8)$ & $8(11.6)$ & $1(1.4)$ & $33(47.8)$ \\
Osteopenia & $8(11.6)$ & $14(20.3)$ & $7(10.1)$ & $29(42.0)$ \\
Osteoporosis & $1(1.4)$ & $2(2.9)$ & $4(5.8)$ & $7(10.1)$ \\
Total & $33(47.8)$ & $24(34.8)$ & $12(17.4)$ & $69(100)$ \\
\hline BMD: Bone Mineral Density & & &
\end{tabular}

Table 3. Lumbar and femur BMD evaluations according to follow-up duration

\begin{tabular}{llccc}
\hline & Region & $\begin{array}{c}\mathbf{1 - 1 2} \\
\text { month }\end{array}$ & $\begin{array}{c}\mathbf{1 2 - 2 4} \\
\text { month }\end{array}$ & $\begin{array}{c}\mathbf{> 2 4} \\
\text { month }\end{array}$ \\
\hline \multirow{2}{*}{ Normal BMD } & Lumbar & $7(38.9)$ & $10(41.7)$ & $16(59.3)$ \\
& Femur & $9(50.0)$ & $10(41.7)$ & $14(51.8)$ \\
\multirow{2}{*}{ Low BMD } & Lumbar & $11(61.1)$ & $14(58.3)$ & $11(40.7)$ \\
& Femur & $9(50.0)$ & $14(58.3)$ & $13(48.2)$ \\
\hline \multirow{2}{*}{ Osteopenia } & Lumbar & $8(44.4)$ & $10(41.7)$ & $6(22.2)$ \\
& Femur & $7(38.9)$ & $12(50.0)$ & $10(37.0)$ \\
\multirow{2}{*}{ Osteoporosis } & Lumbar & $3(16.7)$ & $4(16.6)$ & $5(18.5)$ \\
& Femur & $2(11.1)$ & $2(8.3)$ & $3(11.2)$ \\
\hline BMD: Bone Mineral Density & & &
\end{tabular}

BMD: Bone Mineral Density 
Table 4. Effect of cumulative steroid dose and 25(OH) Vitamin D levels on BMD

\begin{tabular}{|c|c|c|c|c|c|c|}
\hline & & \multicolumn{2}{|c|}{ Normal BMD $(n=33)$} & \multicolumn{2}{|c|}{ BMD Loss (n=36) } & \multirow{2}{*}{$\mathbf{p}$} \\
\hline & & Mean \pm SD & $\operatorname{Median}\left(\mathrm{Q}_{1}-\mathrm{Q}_{3}\right)$ & Mean \pm SD & Median $\left(\mathrm{Q}_{1}-\mathrm{Q}_{3}\right)$ & \\
\hline \multirow{2}{*}{ Cumulative Steroid Dose (mg) } & Lumbar & $6777 \pm 2232$ & $6750(5550-8250)$ & $6125 \pm 1922$ & $6075(4275-7500)$ & 0.197 \\
\hline & Femur & $6427 \pm 2302$ & $6450(5100-8150)$ & $6445 \pm 1901$ & $6225(5325-7725)$ & 0.971 \\
\hline \multirow{2}{*}{$25(\mathrm{OH})$ Vit D (ng/mL) } & Lumbar & $13.8 \pm 11.4$ & $12.3(7.5-16.4)$ & $14.1 \pm 8.6$ & $11.1(7.5-19.6)$ & 0.909 \\
\hline & Femur & $12.3 \pm 6.3$ & $10.4(7.5-15.5)$ & $15.6 \pm 12.3$ & $12.6(7.3-21.5)$ & 0.177 \\
\hline
\end{tabular}

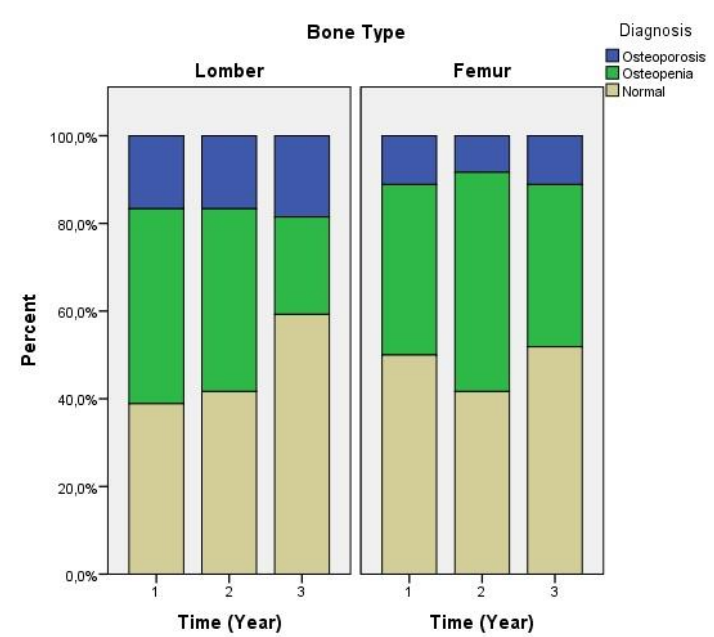

Figure 1. Evaluation of BMD in terms of normal, osteopenia and osteoporosis according to duration of follow-up

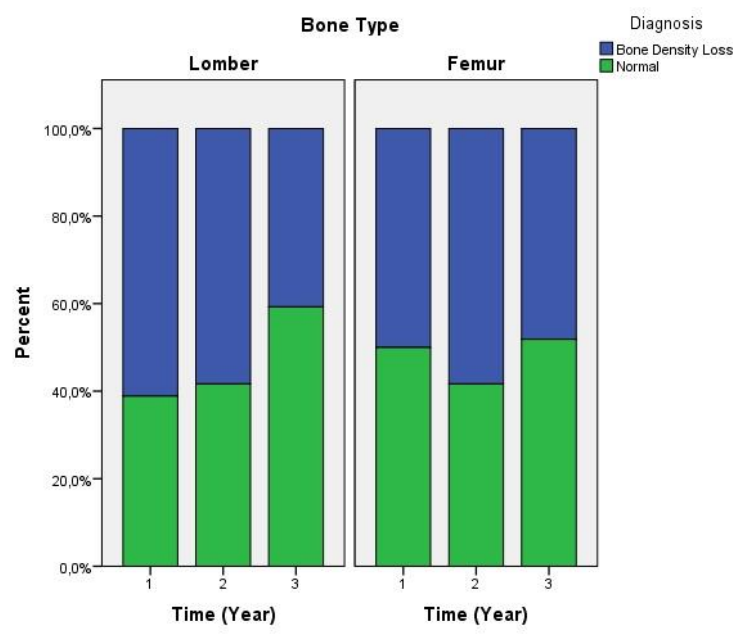

Figure 2. Evaluation of BMD changes of patients by years

In addition, there was no significant correlation between $25(\mathrm{OH})$ vitamin D levels and lumbar BMD measurement $\left(r_{s}=0.036, p=0.771\right)$, and between $25(\mathrm{OH})$ vitamin $D$ levels and femur BMD measurement $\left(r_{s}=-0.015, p=0.905\right)$.

\section{DISCUSSION}

Our findings revealed more extensive BMD loss in the lumbar vs. femur region at the end of the first year than the following years and a cumulative increase in the frequency of osteoporosis in the post-transplantation period. The ratio of patients with adequate $25(\mathrm{OH})$ vitamin $\mathrm{D}$ levels was calculated as $4.3 \%(n=3)$. The majority of patients $(79.7 \%, \mathrm{n}=55)$ had $25(\mathrm{OH})$ vitamin $\mathrm{D}$ deficiency. There was no relation between cumulative steroid dose and BMD loss. Also, no statistically significant relationship was shown between induction therapy and loss of BMD.

Although BMD loss is seen both in the lumbar region and in the femoral neck in the first 6 months of the transplantation, the most intense BMD loss is seen in the lumbar region. BMD loss in the femoral neck becomes prominent after 6 months by follow-up (14). Similar to our study, in the study of Julian et al. (15), 20 post-transplant patients were evaluated and BMD loss was shown to be more intense in the lumbar region in the first 6 months. This can be explained by the different bone structure of lumbar and femur regions. Lumbar region consists mainly of trabecular bone and is a region sensitive to steroid effect. For this reason, BMD loss in the first 6 months is the highest in this region, when glucocorticoid therapy is used at the maximum doses. Femoral neck, on the other hand, is sensitive to hyperparathyroidism as it contains cortical bone. The effects of high parathyroid hormone on femur are long-lasting, as it may take years for the recovery of parathyroid gland hyperplasia after transplantation (16).

Similar to our study, in the literature, it has been shown that BMD loss or osteoporosis during the posttransplantation period reached the highest level in the first 6 months, and continue at a lower rate in the 6-12 months. Although it varies according to the series, the BMD reduction rate in the post transplantation period has been shown to be 5.5-19.5\% for the first 6-month and 2.6-8.2\% for the second 6-month (17). In the study by Trabulus et al. (18), osteoporosis was reported in $15.3 \%$ of patients in the first year, in $37.5 \%$ between $1-3$ years, and in $41.6 \%$ between 3-5 years.

Vitamin 25(OH) D levels, together with calcium and phosphorus metabolism, is one of the factors affecting development, structure and function of the musculoskeletal system. Moderate or severe $25(\mathrm{OH}) \mathrm{D}$ vitamin deficiency has been demonstrated in kidney transplant recipients. This situation varies according to seasons, countries and age. In the studies investigated $25(\mathrm{OH}) \mathrm{D}$ vitamin levels of the recipients, the ratio of patients with adequate vitamin $25(\mathrm{OH})$ D levels was reported to be $3-12 \%$, similar to our findings $(4.3 \%)$ $(19,20)$.

In a study of 86 transplant patients followed for $38.3 \pm 14.8$ years after transplantation, those who received $>5600 \mathrm{mg}$ steroids and those who received $<3300 \mathrm{mg}$ steroids were compared and it was shown that the cumulative steroid dose did not increase the risk of bone fracture (21). In a similar study, 59 patients (31 patients with osteoporosis, 28 patients without osteoporosis) were followed up for $8.5 \pm 3.1$ years after transplantation, and authors reported no significant difference between patients with vs. without 
osteoporosis in terms of cumulative steroid doses (11). However, data from the United States Renal Data System (USRDS) revealed that the fracture risk decreased by $31 \%$ without increasing acute rejection risk in patients who were discharged from hospital by discontinuing steroid treatment (22). Chandran et al. (23) showed a negative correlation between cumulative steroid doses and BMD in a 5-year study with 164 renal transplant patients. In a study of 68 transplant patients, $>40 \%$ of patients were shown to have lumbar BMD loss in first 11 months and bone loss was closely related to the cumulative steroid dose (24).

The limitations of the current study are retrospective design, lack of detailed information on patients' mineral and bone disorders associated with chronic renal disease before transplantation, and lack of data on control BMD measurements after treatment.

\section{CONCLUSION}

In conclusion, $25(\mathrm{OH})$ vitamin D deficiency is commonly encountered in transplant patient population, while BMD loss is also evident, particularly within the first posttransplant year and in the lumbar region. However, no relationship has been demonstrated between induction therapy and loss of BMD. Conflicting data exists in the literature regarding the effects of cumulative steroid doses and immunosuppressive treatments on BMD. Further studies are needed to address BMD, potential treatments and treatment outcome in transplant patients.

\section{Conflict of interest: None \\ Financial support: None}

\section{REFERENCES}

1. Nair SS, Lenihan CR, Montez-Rath ME, Lowenberg DW, Chertow GM, Winkelmayer WC. Temporal trends in the incidence, treatment and outcomes of hip fracture after first kidney transplantation in the United States. Am J Transplant. 2014;14(4):943-51.

2. Arnold J, Mytton J, Evison F, Gill PS, Cockwell P, Sharif A, et al. Fractures in kidney transplant recipients: a comparative study between England and New York State. Exp Clin Transplant. 2018;16(4):410-8.

3. Ferro CJ, Arnold J, Bagnall D, Ray D, Sharif A. Fracture risk and mortality post-kidney transplantation. Clin Transplant. 2015;29(11):1004-12.

4. Messa P, Sindici C, Cannella G, Miotti V, Risaliti A, Gropuzzo $\mathrm{M}$, et al. Persistent secondary hyperparathyroidism after renal transplantation. Kidney Int. 1998;54(5):1704-13.

5. Weisinger JR, Carlini RG, Rojas E, Bellorin-Font E. Bone disease after renal transplantation. Clin J Am Soc Nephrol. 2006;1(6):1300-13.

6. Canalis E. Mechanisms of glucocorticoid-induced osteoporosis. Curr Opin Rheumatol. 2003;15(4):454-7.

7. Epstein S, Jee WS, Ma Y, Liu CC. Comments on "cyclosporin does not affect the absolute rate of cortical bone resorption at the organ level in the growing rat". Calcif Tissue Int. 1995;56(6):588-92.

8. Goffin E, Devogelaer JP, Lalaoui A, Depresseux G, De Naeyer P, Squifflet JP, et al. Tacrolimus and low-dose steroid immunosuppression preserves bone mass after renal transplantation. Transpl Int. 2002;15(2-3):73-80.

9. Lewin E, Colstrup H, Pless V, Ladefoged J, Olgaard K.
A model of reversible uremia employing isogenic kidney transplantation in the rat. Reversibility of secondary hyperparathyroidism. Scand J Urol Nephrol. 1993;27(1):115-20.

10. Altman AM, Sprague SM. Mineral and bone disease in kidney transplant recipients. Curr Osteoporos Rep. 2018;16(6):703-11.

11. Durieux S, Mercadal L, Orcel P, Dao H, Rioux C, Bernard $\mathrm{M}$, et al. Bone mineral density and fracture prevalence in long-term kidney graft recipients. Transplantation. 2002;74(4):496-500.

12. Marcen R, Caballero C, Uriol O, Fernandez A, Villafruela JJ, Pascual J, et al. Prevalence of osteoporosis, osteopenia, and vertebral fractures in long-term renal transplant recipients. Transplant Proc. 2007;39(7):2256-8.

13. McGregor R, Li G, Penny H, Lombardi G, Afzali B, Goldsmith DJ. Vitamin D in renal transplantation from biological mechanisms to clinical benefits. Am J Transplant. 2014;14(6):1259-70.

14. Alshayeb HM, Josephson MA, Sprague SM. CKDmineral and bone disorder management in kidney transplant recipients. Am J Kidney Dis. 2013;61(2):310-25.

15. Julian BA, Laskow DA, Dubovsky J, Dubovsky EV, Curtis JJ, Quarles LD. Rapid loss of vertebral mineral density after renal transplantation. $\mathrm{N}$ Engl J Med. 1991;325(8):544-50.

16. Kodras K, Haas M. Effect of kidney transplantation on bone. Eur J Clin Invest. 2006;36(Suppl 2):63-75.

17. Taweesedt PT, Disthabanchong S. Mineral and bone disorder after kidney transplantation. World $\mathbf{J}$ Transplant. 2015;5(4):231-42.

18. Trabulus S, Apaydin S, Altiparmak MR, Seyahi N, Sariyar M, Serdengecti K, et al. Osteoporosis after renal transplantation. Nefrologia. 2003;23(Suppl 2):127-30.

19. Sadlier DM, Magee CC. Prevalence of $25(\mathrm{OH})$ vitamin $\mathrm{D}$ (calcidiol) deficiency at time of renal transplantation: a prospective study. Clin Transplant. 2007;21(6):683-8.

20. Stavroulopoulos A, Cassidy MJ, Porter CJ, Hosking DJ, Roe SD. Vitamin D status in renal transplant recipients. Am J Transplant. 2007;7(11):2546-52.

21. Vautour LM, Melton LJ 3rd, Clarke BL, Achenbach SJ, Oberg AL, McCarthy JT. Long-term fracture risk following renal transplantation: a population-based study. Osteoporos Int. 2004;15(2):160-7.

22. Nikkel LE, Mohan S, Zhang A, McMahon DJ, Boutroy $S$, Dube $G$, et al. Reduced fracture risk with early corticosteroid withdrawal after kidney transplant. Am J Transplant. 2012;12(3):649-59.

23. Chandran M, Hao Y, Kwee AK, Swee DS, Ng DCE, Kee TYS, et al. Addressing bone quality and bone density after renal transplantation: A prospective evaluation of the evolution of trabecular bone score and bone mineral density over the first 5 years following renal transplantation in Asian patients. Clin Transplant. 2019;33(10):e13671.

24. Bayat N, Einollahi B, Pourfarzian V, Alishiri G, Nemati E, Bagheri $\mathrm{N}$, et al. Bone mineral density changes within 11 months of renal transplantation in Iranian patients. Transplant Proc. 2007;39(4):1039-43. 